\title{
Inclusion complex of amiodarone hydrochloride with cyclodextrins: preparation, characterization and dissolution rate evaluation
}

\author{
Alexandre Machado Rubim*1,2, Jaqueline Bandeira Rubenick', Marcela Maurer², \\ Luciane Varini Laporta ${ }^{1,2}$, Clarice Madalena Bueno Rolim ${ }^{1}$
}

\begin{abstract}
${ }^{1}$ Postgraduate Program in Pharmaceutical Sciences, Federal University of Santa Maria, Santa Maria, RS, Brazil, ${ }^{2}$ Laboratory Drug Quality Control, Franciscan University Center, Santa Maria, RS, Brazil
\end{abstract}

\begin{abstract}
This study aimed to improve the water solubility of amiodarone hydrochloride (AMH) via inclusion complexes with $\beta$-cyclodextrin, methyl- $\beta$-cyclodextrin and 2-hydroxypropyl- $\beta$-cyclodextrin. Inclusion complexes were developed by physical mixture, coevaporation, spray-drying and freeze-drying. Solid state analysis was performed using X-ray powder diffraction, differential scanning calorimetry and scanning electronic microscopy. Thermodynamic studies demonstrate that the inclusion complexes of drug into different cyclodextrins were an exothermic process that occurred spontaneously. Water solubility and drug dissolution rates were significantly increased after the formation of inclusion complexes with the cyclodextrins evaluated in relation to the physical mixture and pure drug. The present study provides useful information for the potential application of complexation with amiodarone HCl. This may be a good strategy for the development of solid pharmaceutical dosage forms.
\end{abstract}

Uniterms: Amiodarone $\mathrm{HCl} /$ evaluation. Amiodarone $\mathrm{HCl} /$ solubility. Cyclodextrins/inclusion complexes. Cyclodextrins / thermodynamic studies. Dissolution rate.

\section{INTRODUCTION}

Amiodarone hydrochloride (AMH), chemically known as (2-butylbenzofuran-3-yl)[4-[2-(diethylamino) ethoxy]-3,5-diiodophenyl]methanone hydrochloride, used for the treatment of both supraventricular and ventricular arrhythmias (Lafuente-Lafuente et al., 2009). AMH is a white or almost white, crystalline powder and is very slightly soluble in water $\left(0.2-0.5 \mathrm{mg} \mathrm{mL}^{-1}\right)$ (British Pharmacopoeia, 2012; Eghrary et al., 2012). According to the Biopharmaceutical Classification System (BCS), AMH is a class II. Class II drugs are those with low solubilities and high permeabilities (Amidon et al., 1995; Benet, 2005).

For drugs with low gastrointestinal solubility and high permeability, dissolution in physiological fluids is the limiting step for oral bioavailability. These properties are a challenge for the pharmaceutical industry, since more than $70 \%$ of the new drugs have low solubility showing

\footnotetext{
*Correspondence: A. M. Rubim. Laboratório de Controle de Qualidade de Medicamentos. Centro Universitário Franciscano. 97010032 - Santa Maria - RS, Brasil. E-mail: alexandre.rubim01@gmail.com
}

deficient biopharmaceutical properties (Ku, Dublin, 2012; Leuner, Dressman, 2000; Riekes et al., 2010; Svenson, 2009; Vasconcelos, Sarmento, Costa, 2007).

In order to improve drug solubility in physiological fluids, their effectiveness should be increased, and the doses administered and toxic effects reduced. Several strategies can be employed, such as development of solid dispersion, inclusion complexes containing cyclodextrin, chemical modification, particle micronization, $\mathrm{pH}$ adjustment, micellar solubilization and supercritical fluid (Adeli, 2014; Alves et al., 2014; Chaudhary et al., 2012; Frizon et al., 2013; Gursoy, Benita, 2004; Jagdale et al., 2012; Li-hong et al., 2013; Lu et al., 2012; Maulvi et al., 2011; Patel et al., 2008; Sathigari et al., 2009).

Cyclodextrins (CDs) are cyclic organic compounds composed of different D-glucopyranose units. CDs containing six, seven or eight natural glucose units obtained in high quantity called $\alpha$-cyclodextrin $(\alpha-C D)$, $\beta$-cyclodextrin $(\beta-C D)$ and $\gamma$-cyclodextrin $(\gamma-C D)$, respectively. These structures showed different values of solubility in water and at the same time are capable of hosting hydrophobic molecules (Loftsson, Brewster, 1996; Rajewski, Stella, 1996; Uekama, 2004). 
This work aimed to develop inclusion complexes using cyclodextrins for the purpose of improving water solubility and dissolution rate of AMH. The solid state physicochemical properties were assessed using powder $\mathrm{X}$-ray diffraction, differential scanning calorimetry, Fourier-transform infrared spectroscopy and scanning electron microscopy. Furthermore, in vitro dissolution profiles using different dissolution media were performed to investigate the increased solubility of this drug.

\section{MATERIAL AND METHODS}

\section{Material}

AMH (purity $>99 \%$ ) was obtained from Brazilian Pharmacopeia, batch 1040. The raw material AMH batch: CAD20131006 (purity $>99 \%$ ) was purchased from Zhejiang Pharmaceutica $^{\circledR}$ (Hong Kong, China). $\beta$-Cyclodextrin $(\beta-C D)$, methyl- $\beta$-cyclodextrin, (Methyl- $\beta-C D)$ and hydroxypropyl- $\beta$-cyclodextrin (HP- $\beta-C D$ ), with an average degree of molar substitution per anhydroglucose unit of 0.6 , purchased from Sigma-Aldrich ${ }^{\circledR}$ (St. Louis, MO, USA). Ultra-pure deionized water was generated from a Millipore Milli-Q Gradient System (Billerica, MA, USA). Other reagents and solvents used were of analytical grade.

\section{Preparation of physical mixture and inclusion complexes}

Physical mixture and inclusion complexes of AMH and $\mathrm{CDs}$ at a 1:1 molar ratio were performed by different techniques:

Physical mixture (PM): The PM was prepared by mixing previously weighed powders in a ceramic mortar for $10 \mathrm{~min}$.

Coevaporation (CE): The product was prepared by dissolving a known amount of AMH and CDs in suitable volumes of water:ethanol (1:1) solution. The mixture was stirred for 2 hours and then solvent was removed in a vacuum oven at $40^{\circ} \mathrm{C}$ for 72 hours.

Freeze-drying (FD): The product was prepared by dissolving the CDs in water:ethanol (1:1) solution and adding a known amount of AMH. The mixture was agitated for $5 \mathrm{~h}$ at $40^{\circ} \mathrm{C}$ and organic solvent was evaporated by rotary evaporation at $40^{\circ} \mathrm{C}$ under reduced pressure (-700 mm Hg) (Fisatom ${ }^{\circledR}$, model 802). The solution was placed in a freezer at $-80{ }^{\circ} \mathrm{C}$ for 24 hours and lyophilized in a Jouan LP3 (model 60) freeze-dryer for 24 hours.
Spray-drying (SD): The product was prepared by dissolving the CDs in water:ethanol (1:1) solution and adding a known amount of AMH. The mixture was agitated for $24 \mathrm{~h}$ at $25^{\circ} \mathrm{C}$. The mixture was spray-dried using a LabMaq Brazil ${ }^{\circledR}$ (model MSDi 1.0 ) spray dryer under the following conditions: sample feed rate of $4 \mathrm{~mL} /$ min, inlet temperature $135^{\circ} \mathrm{C}$, outlet temperature $105^{\circ} \mathrm{C}$ and air flow rate of $45 \mathrm{~L} / \mathrm{min}$.

\section{pH-Dependent solubility and Phase solubility studies}

The $\mathrm{pH}$-dependent solubility studies were determined in $\mathrm{pH} 1.2,4.5$ and 6.8 buffer solution and distilled water at $37{ }^{\circ} \mathrm{C} \pm 0.5^{\circ} \mathrm{C}$. An excess quantity of $\mathrm{AMH}$ was placed in an erlenmeyer flask containing 10 $\mathrm{mL}$ of different solutions. The samples were covered to avoid solvent loss and then shaken at $140 \mathrm{rpm}$ in an orbital shaking incubator (Novatecnica ${ }^{\circledR}$, NT712) for 24 hours. After equilibrium, samples were centrifuged at $4000 \mathrm{rpm}$ for 10 minutes, and then the concentration of AMH in supernatant liquid was determined by HPLC (Rubim et al., 2015).

The phase solubility studies were performed according to the method reported by Higuchi and Connors (1965). Briefly, an excess amount of AMH was transferred to an erlenmeyer flask containing $10 \mathrm{~mL}$ cyclodextrins in aqueous solutions at concentrations ranging from 0 to $10.0 \mathrm{mM}$. The flasks were covered to avoid solvent loss and then shaken at $140 \mathrm{rpm}$ in an orbital shaking incubator for 24 hours at different temperatures $25^{\circ} \mathrm{C}$ and $37^{\circ} \mathrm{C} \pm 0.5^{\circ} \mathrm{C}$. After equilibrium, samples were centrifuged at $4000 \mathrm{rpm}$ for 10 minutes, and then the concentration of AMH in supernatant liquid was determined by HPLC. All the experiments were performed in triplicate. The apparent complexation constants $\left(\mathrm{K}_{1: 1}, \mathrm{M}^{-1}\right)$ of the complexes were determined in accordance with Eq. (1) from phase solubility slope, where the intercept is the intrinsic solubility of drug absence of cyclodextrins.

$$
K_{1: 1}=\frac{\text { Slope }}{\text { Intercept }(1-\text { Slope })}
$$

Thermodynamic parameters were obtained as a function of the temperature and complexation constant. The changes in Gibb's free energy $(\Delta \mathrm{G})$, enthalpy $(\Delta H)$ and entropy $(\Delta S)$ were determined using $(\mathrm{Eq}(2),(3)$ and (4)), respectively, where $R$ is the gas constant $(8.314 \mathrm{~J}$ $\mathrm{mol}^{-1} \mathrm{~K}^{-1}$ ) and $T$ is temperature in Kelvin.

$$
\Delta G=-R T \ln K
$$




$$
\begin{gathered}
\ln \left(\frac{K_{2}}{K_{1}}\right)=\Delta H \frac{T_{2}-T_{1}}{R T_{2} T_{1}} \\
\Delta S=\frac{(\Delta H-\Delta G)}{T}
\end{gathered}
$$

\section{Characterization of the inclusion complex}

\section{$X$-ray powder diffraction analysis $(X R D)$}

The diffraction patterns of samples were obtained with a X-ray diffractometer (Rigaku ${ }^{\circledR}$, Miniflex 300), using $\mathrm{Cu}$ as an anode material, operated at a voltage of $10 \mathrm{~mA}$, $30 \mathrm{kV}$, monochromatic radiation $(\lambda=1.54051 \AA)$. The samples were analyzed from $5^{\circ}$ to $50^{\circ}$ in the range of $2 \theta$, in increments of $0.09 \%$.

\section{Differential Scanning Calorimetry (DSC)}

The DSC studies were obtained in a DSC-60 cell $\left(\right.$ Shimadzu ${ }^{\circledR}$ ) with a sensibility of $0.1^{\circ} \mathrm{C}$, using aluminum crucibles with about $2 \mathrm{mg}$ of sample. The temperature of analysis was 30 to $300{ }^{\circ} \mathrm{C}$, with a heating rate of $10^{\circ} \mathrm{C} \mathrm{min}^{-1}$ in a nitrogen atmosphere with a flow rate of $100 \mathrm{~mL} \mathrm{~min}^{-1}$.

\section{Scanning Electron Microscopy (SEM)}

With the help of the scanning electron microscope (Philips, Model XL 30) at an intensity of $10 \mathrm{kV}$, the samples were mounted onto a metallic base using doublesided adhesive tape vacuum-coated with gold.

\section{Dissolution studies}

The dissolution studies were performed in $500 \mathrm{~mL}$ dissolution medium (i.e. water, acid buffer $\mathrm{pH} 1.2$, acetate buffer $\mathrm{pH} 4.5$ and phosphate buffer 6.8 ) at $37{ }^{\circ} \mathrm{C} \pm 0.5^{\circ} \mathrm{C}$ using USP Apparatus 2 at $50 \mathrm{rpm}$. Briefly, AMH (50 mg), the physical mixture (PM) and inclusion complexes containing equivalent amount of AMH were separately added into vessel at a rotation speed of $50 \mathrm{rpm}$. At a prespecified interval time, samples $(10 \mathrm{~mL})$ were collected and replaced with an equal volume of fresh medium to maintain a constant total volume. The percentage of drug dissolved was determined using the HPLC method.

\section{RESULTS AND DISCUSSION}

\section{pH-Dependent solubility and Phase solubility studies}

The solubility of AMH as a function of $\mathrm{pH}$ was determined in various aqueous media (water, acid buffer $\mathrm{pH} 1.2$, acetate buffer $\mathrm{pH} 4.5$ and phosphate buffer $\mathrm{pH}$ 6.8). The solubility values found were: in water, $21.86 \pm$ $1.6011 \mu \mathrm{g} \mathrm{mL}^{-1}$; in acid buffer $\mathrm{pH} 1.2,8.33 \pm 0.1162 \mu \mathrm{g}$ $\mathrm{mL}^{-1}$; in acetate buffer $\mathrm{pH} 4.5,26.93 \pm 0.2944 \mu \mathrm{g} \mathrm{mL}^{-1}$; in phosphate buffer $\mathrm{pH} 6.8,1.18 \pm 0.0877 \mu \mathrm{g} \mathrm{mL}^{-1}$. In solutions with low $\mathrm{pH}$ the $\mathrm{AMH}$ has appreciable solubility due to its basic nature and ionization $(6.56 \pm 0.06)$. On the other hand it is obvious that AMH shows low solubility in a higher $\mathrm{pH}$ solution in which it remains in a unionized form (Lamprecht, Bouligand, Benoit, 2002; Paduraru et al., 2013).

The solubility behaviors found are according to the low solubility obtained with acid buffer $\mathrm{pH}$ 1.2. This can be explained as due to the formation of insoluble complex between drug and anions dissolved in buffer solution (Avdeef, 2007; Boury et al., 2001; Ravin, Shami, Rattie, 1975).

Phase solubility studies were used for the evaluation of $\mathrm{AMH}$ behavior in an aqueous solution of $\beta-\mathrm{CD}$, methyl- $\beta-\mathrm{CD}$ and $\mathrm{HP}-\beta-\mathrm{CD}$ at 25 and $37^{\circ} \mathrm{C}$. The results are shown in Figure 1. AMH solubility linearly increased with increasing concentrations of cyclodextrins over the concentration range evaluated.

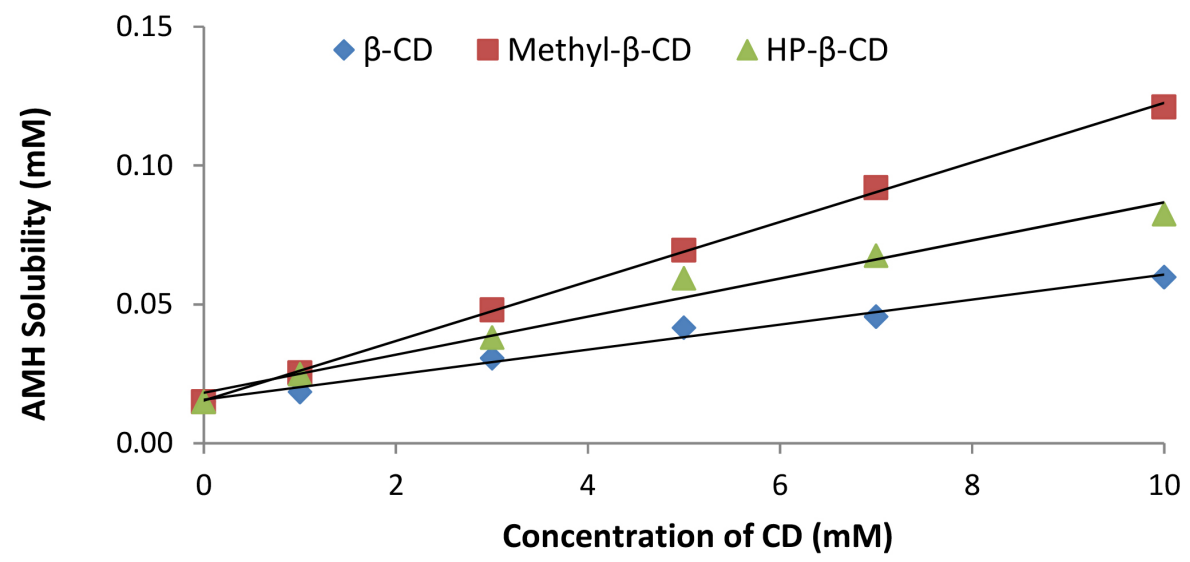

FIGURE 1 - Phase solubility diagrams of AMH in the presence of cyclodextrins in (A) $25^{\circ} \mathrm{C}$ and (B) $37{ }^{\circ} \mathrm{C} \pm 0.5^{\circ} \mathrm{C}(n=3)$. 
The diagrams obtained were classified as $\mathrm{A}_{\mathrm{L}}$ type, according to Higuchi and Connors (1965). This classification is observed when the guest solubility increases linearly with the cyclodextrin concentration, over the concentration range evaluated, indicating a 1:1 molecular complex formation between AMH and different cyclodextrins. The solubility of AMH in water increased significantly (more than 7, 14 and 9-fold at $25{ }^{\circ} \mathrm{C}$ ) for $\beta-\mathrm{CD}$, Methyl- $\beta-\mathrm{CD}$ and HP- $\beta$-CD at 10 $\mathrm{mM}$, respectively and (more than 4,8 and 5 -fold at $37{ }^{\circ} \mathrm{C}$ ) for $\beta-C D$, Methyl- $\beta-C D$ and HP- $\beta-C D$ at 10 $\mathrm{mM}$, respectively. This increased solubility can be explained by the formation of an inclusion complex with cyclodextrins. The thermodynamics parameters $\left(\mathrm{K}_{1: 1}, \Delta \mathrm{G}, \Delta H, \Delta S\right)$ were calculated from the slopes of the linear phase-solubility plots, and are summarized in Table I.

The high $\left(\mathrm{K}_{1: 1}\right)$ values were observed for all cyclodextrins evaluated in this study, indicating the formation of a stable complex. The stability constants were highest for the complex formed with Methyl- $\beta-C D$, followed by HP- $\beta-C D$ and $\beta-C D$. It has been suggested that the steric effect, which depends on the size of cyclodextrins, is one of the main factors of inclusion complex formation (Del Valle, 2004).

Furthermore the $\Delta \mathrm{G}$ values were negative for all complexes, indicating that the inclusion of AMH in the different cyclodextrins is a spontaneous process and thermodynamically favorable. This increase in solubility is directly associated with values of $\Delta \mathrm{G}_{\mathrm{tr}}<0$ being proportional to the increased carrier concentration (Patel et al., 2008). The values of the enthalpy change $(\Delta \mathrm{H})$ were negative, indicating that the interaction between $\mathrm{AMH}$ and cyclodextrins is an exothermic process, nonetheless the magnitude of the change suggests that the interactions were of the low energy type.

\section{Characterization of the complexes}

\section{$X$-ray powder diffraction analysis}

$\mathrm{X}$-ray analysis is a tool utilized to characterize the crystalline state, to evaluate the different crystalline forms and also to confirm the formation of host-guest inclusion complexes. The solid state form of the particles as amorphous, crystalline or polymorphic is a parameter that determines the solubility and dissolution rate of drugs (Markovich et al., 1997). Figure 2 shows the diffractogram pattern of AMH and corresponding inclusion complexes with CDs prepared by different methods.

Figure 2 shows the intense peaks of crystalline state of the drug structure and the influence that each $\mathrm{CD}$ and preparation method can have on the crystalline state of the drug. The PM product using the three carriers showed a diffractogram pattern similar to that of the pure drug. The CE method using $\beta$-CD showed a similar diffractogram to that of PM, while those obtained by SD and FD methods showed the absence of any peaks indicating a transition from crystalline to an amorphous state. Similar results were observed with Methyl- $\beta$ $\mathrm{CD}$ and HP- $\beta$-CD by spray-drying and freeze-drying methods. This solid state form transition was also observed by Bankar and Mahatma (2012), Paduraru et al. (2013) and Riekes et al. (2010), when the amorphization of the compounds after complexation with cyclodextrins was demonstrated.

\section{Thermal analysis}

DSC is a tool utilized in the pharmaceutical industry for the purpose of evaluating the physicochemical properties of drugs and excipients, evaluation of degradation kinetics and stability. Furthermore, these analyses are commonly used to characterize the solid state inclusion complexes (Vecchio et al., 2001;

TABLE I - Thermodynamic parameters obtained from phase solubility studies with AMH and cyclodextrins at different temperatures (values are the mean $\pm \mathrm{SD}$ of triplicate experiments)

\begin{tabular}{lcccccc}
\hline Systems & $\mathrm{T}^{\mathrm{A}}$ & $\mathrm{S}_{\mathrm{o}}^{\mathrm{B}}$ & $\mathrm{K}_{1: 1}{ }^{\mathrm{C}}$ & $\Delta \mathrm{G}^{\mathrm{D}}$ & $\Delta S^{\mathrm{E}}$ & $\Delta H^{\mathrm{F}}$ \\
\hline \multirow{2}{*}{ AMH: $\beta-\mathrm{CD}$} & 25 & $0.009 \pm 0.001$ & $446.23 \pm 2.1985$ & $-15.12 \pm 0.8952$ & $-58.46 \pm 0.9211$ & \multirow{2}{*}{$32.55 \pm 0.3911$} \\
& 37 & $0.015 \pm 0.002$ & $268.46 \pm 1.6874$ & $-14.42 \pm 1.0283$ & $-58.46 \pm 0.0391$ & \\
\hline \multirow{2}{*}{ AMH:Methyl- $\beta-C D$} & 25 & $0.008 \pm 0.004$ & $1135.22 \pm 2.2021$ & $-17.44 \pm 1.2418$ & $-23.51 \pm 0.7769$ & \multirow{2}{*}{$24.45 \pm 1.5885$} \\
& 37 & $0.013 \pm 0.004$ & $775.19 \pm 1.5733$ & $-17.16 \pm 0.8496$ & $-23.50 \pm 1.2059$ & \\
\hline \multirow{2}{*}{ AMH:HP- $\beta-C D$} & 25 & $0.011 \pm 0.003$ & $458.72 \pm 2.9982$ & $-15.19 \pm 1.8541$ & $-38.16 \pm 1.3361$ & \multirow{2}{*}{$20.10 \pm 1.0211$} \\
\hline
\end{tabular}

${ }^{\mathrm{A}}$ Temperatures evaluated in $\left({ }^{\circ} \mathrm{C}\right) ;{ }^{\mathrm{B}}$ Solubility of AMH in the absence of cyclodextrins $(\mathrm{mM}) ;{ }^{\mathrm{C}}$ Apparent complexation constant $\left(\mathrm{M}^{-1}\right) ;{ }^{\mathrm{D}}$ Change in Gibbs-free energy $\left(\mathrm{KJ} \mathrm{mol}^{-1}\right) ;{ }^{\mathrm{E}}$ Change in entropy $\left(\mathrm{J} \mathrm{mol}^{-1} \mathrm{~K}^{-1}\right)$; ${ }^{\mathrm{F}}$ Change in enthalpy $\left(\mathrm{KJ}^{\mathrm{mol}}{ }^{-1}\right)$. 

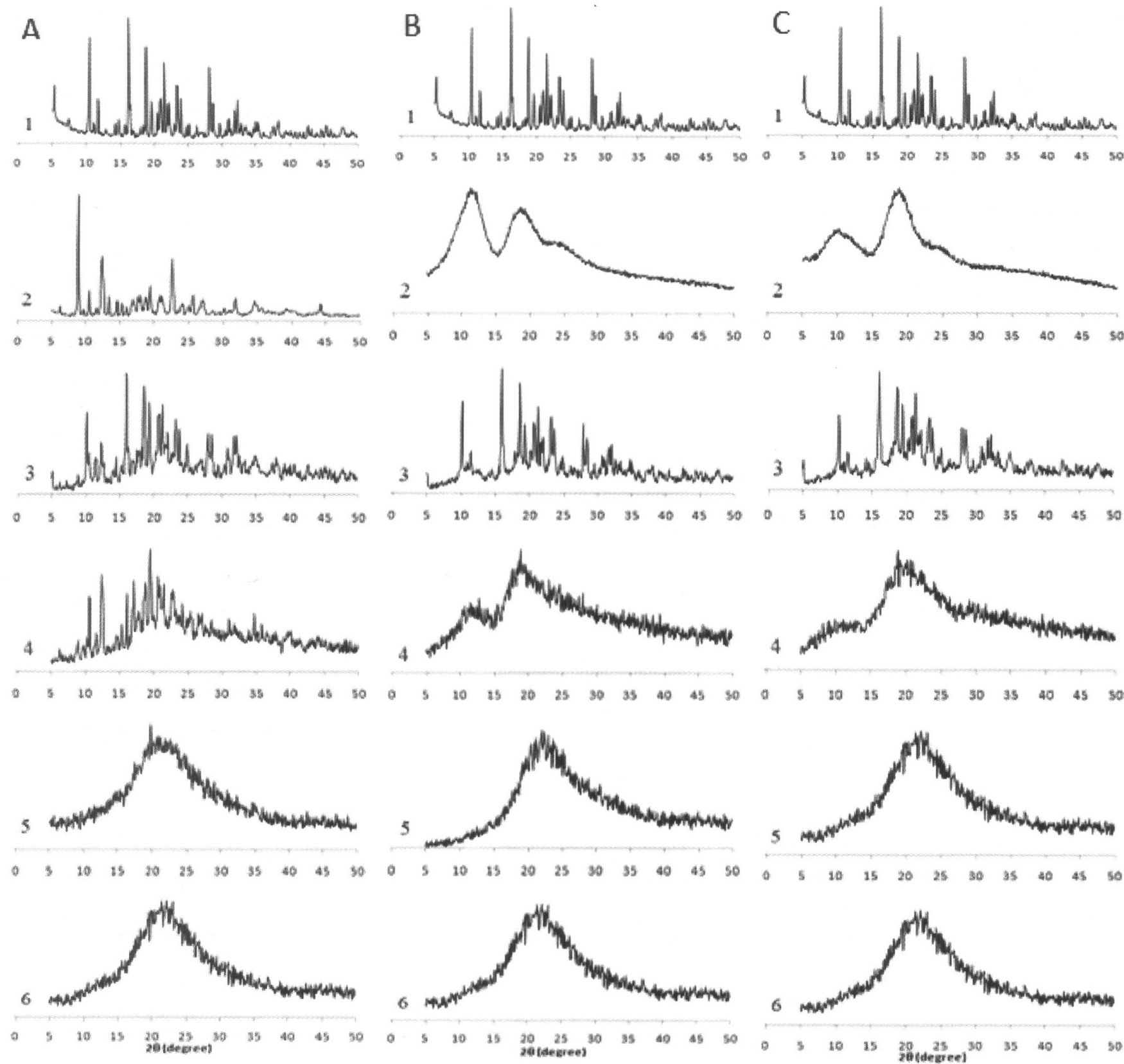

FIGURE 2 - X-ray diffractograms corresponding to: (A): 1 - AMH, 2 - $\beta$-CD, 3 - AMH/ $\beta-\mathrm{CD} / \mathrm{PM}, 4-\mathrm{AMH} / \beta-\mathrm{CD} / \mathrm{CE}, 5-\mathrm{AMH} / \beta$ $\mathrm{CD} / \mathrm{SD}, 6-\mathrm{AMH} / \beta-\mathrm{CD} / \mathrm{FD},(\mathrm{B}): 1$-AMH, 2 - Methyl- $\beta-\mathrm{CD}, 3$ - AMH/Methyl- $\beta$-CD/PM, 4 -AMH/Methyl- $\beta$-CD/CE, 5 - AMH/ Methyl- $\beta-\mathrm{CD} / \mathrm{SD}, 6-\mathrm{AMH} / \mathrm{Methyl}-\beta-\mathrm{CD} / \mathrm{FD}$ and $(\mathrm{C}): 1$ - AMH, 2 - HP- $\beta-\mathrm{CD}, 3-\mathrm{AMH} / \mathrm{HP}-\beta-\mathrm{CD} / \mathrm{PM}, 4-\mathrm{AMH} / \mathrm{HP}-\beta-\mathrm{CD} / \mathrm{CE}$, 5 - AMH/HP- $\beta-\mathrm{CD} / \mathrm{SD}, 6$ - AMH/HP- $\beta-\mathrm{CD} / \mathrm{FD}$.

Yoshida et al., 2011). The thermal behavior of the drug, cyclodextrins and inclusion complexes are presented in Figure 3.

The DSC curve shows that AMH has a sharp melting endothermic peak at about $163.47^{\circ} \mathrm{C}$, indicating a typical behavior of the anhydrous crystalline state. This DSC curve was similar to those in other studies (Paduraru et al., 2013, Riekes et al., 2010). During the DSC analysis the thermogram of HP- $\beta-C D$ showed a very broad endothermic peak between $60^{\circ} \mathrm{C}$ and $110^{\circ} \mathrm{C}$. The formulations produced by different methods containing the three cyclodextrins showed a reduction of intensity and an alteration in position of the endothermic peak of the drug. When the spray-drying method was utilized, the complete disappearance of the endothermic peak corresponding to $\mathrm{AMH}$ was evident, indicating the formation of an amorphous inclusion complex that was confirmed by the results obtained after XRD analysis. 


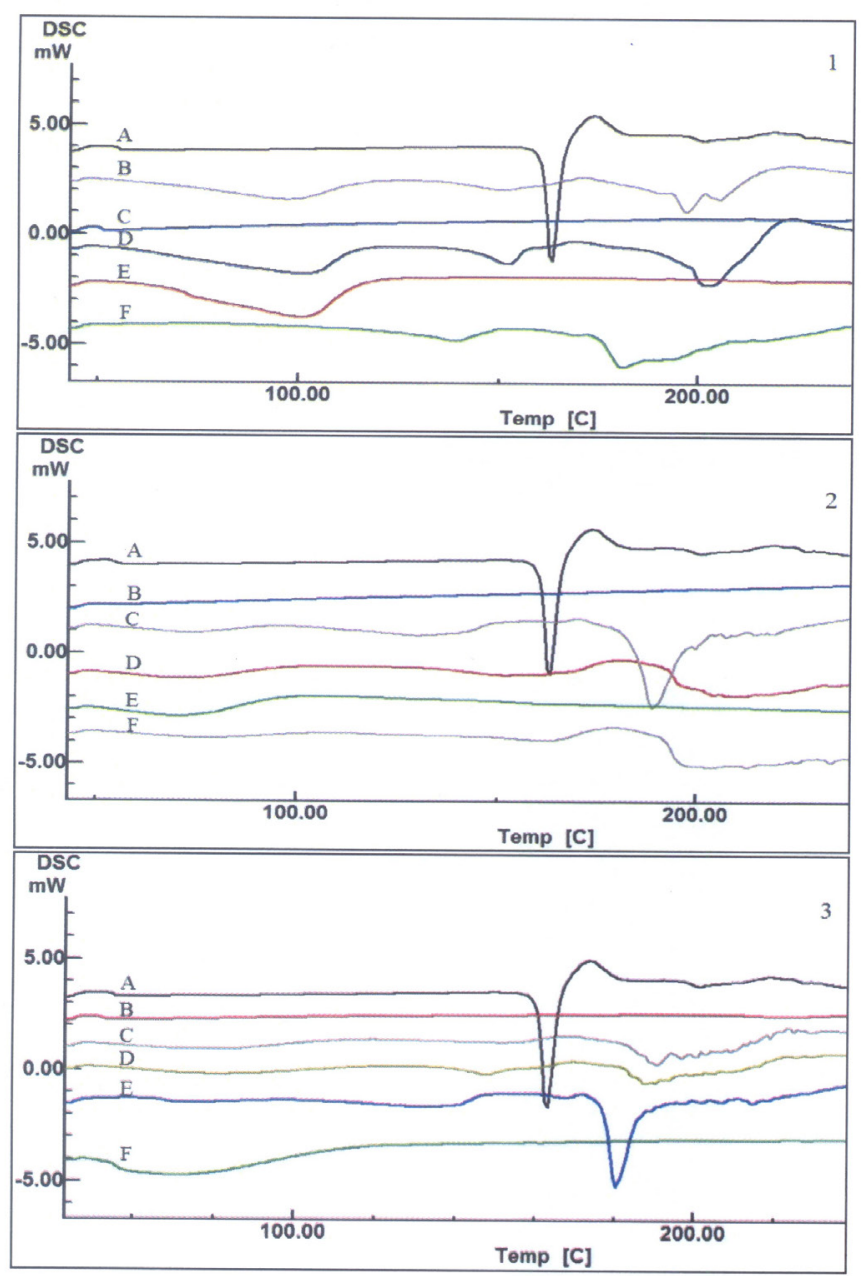

FIGURE 3 - DSC thermograms: 1: (A) AMH powder, (B) physical mixture, (C) spray-dried, (D) coevaporated, (E) $\beta$-CD and (F) freeze-dried; 2: (A) AMH powder, (B) spray-dried, (C) coevaporated, (D) physical mixture, (E) freeze-dried and (F) Methyl- $\beta$-CD; and 3: (A) AMH powder, (B) spray-dried, (C) coevaporated, (D) physical mixture, (E) freeze-dried and (F) HP- $\beta-C D$.

\section{Scanning electron microscopy}

The images obtained for the formulations are presented in Figure 4. The micrographs are used to evaluate the morphological aspects of polymers, solid dispersions, drugs, cyclodextrins and inclusion complexes (Naidu et al., 2004).

AMH showed the irregular size and characteristic morphology of drug crystals, which is in accordance with the X-ray analysis that showed the crystalline nature of AMH. It was also evident that $\beta-C D$ is a crystalline solid while Methyl- $\beta-C D$ and $\mathrm{HP}-\beta-\mathrm{CD}$ are regular and spherical particles.

In the physical mixtures and coevaporation method the AMH crystals were clearly detectable on the surface of cyclodextrins indicating little complexation between compounds. All spray dried powders showed an interaction between drug and cyclodextrins, indicated by the complete disappearance of the crystalline morphology of AMH. This drastic change of morphology and particle shape was indicative of the formation of the new solid phase. Results obtained by others evaluations, DSC and X-ray powder corroborated the formation of an amorphous system.

\section{Dissolution rate studies}

In drugs that present low gastrointestinal solubility and high permeability, in this case $\mathrm{AMH}$, the oral drug release is a limiting step for bioavailability. The bioavailability depends on a series of factors, including the physicochemical properties of its formulation, and the physiological state of the patients (Fernandes, Vieira, Veiga, 2002).

To evaluate whether the inclusion complexes affected the dissolution rates of AMH, dissolution profiles were performed on pure drug, physical mixtures and inclusion complexes with cyclodextrins, with three $\mathrm{pH}$ values and water. Rapid dissolution rate as compared with the pure drug is the characteristic behavior of inclusion complexes (Baboota, Dhaliwal, Kohli, 2005). Dissolution profiles for the pure AMH, physical mixture of the drug and inclusion complexes obtained by different methods are presented in Figure 5.

Pure AMH shows about $22.20 \%$ dissolution in water, $7.83 \%, 18.31 \%$ and $4.82 \%$ dissolution in acid buffer $\mathrm{pH}$ 1.2 , acetate buffer $\mathrm{pH} 4.5$ and phosphate buffer $\mathrm{pH} 6.8$, respectively after 60 minutes of study. As expected, AMH is a drug that depends on the $\mathrm{pH}$ value due to the presence of a tert-amine ionizable in different fluids (Paduraru et al., 2013).

The physical mixtures containing the three cyclodextrins show a similar dissolution rate of about $30 \%$ at 60 minutes in water and acetate buffer $\mathrm{pH} 4.5$. The increment in the dissolution rate of AMH with the physical mixture can be explained by improved drug wettability due to the presence of the cyclodextrins, which can reduce the interfacial tension between particle and dissolution medium. The coevaporation, spray-drying and freeze-drying methods of $\beta-C D$, Methyl- $\beta-C D$ and HP- $\beta$-CD showed a significant increase in drug dissolution compared to physical mixture. This can be attributed to the better interaction between drug and CDs, as confirmed by physicochemical characterization.

The spray-drying products with methyl- $\beta-C D$ showed about $55 \%, 56 \%, 65 \%$ and $38 \%$ dissolution in water, acid buffer $\mathrm{pH} 1.2$, acetate buffer $\mathrm{pH} 4.5$ and phosphate buffer $\mathrm{pH} 6.8$, respectively. The great influence of methyl- $\beta-C D$ can be explained based on its good 


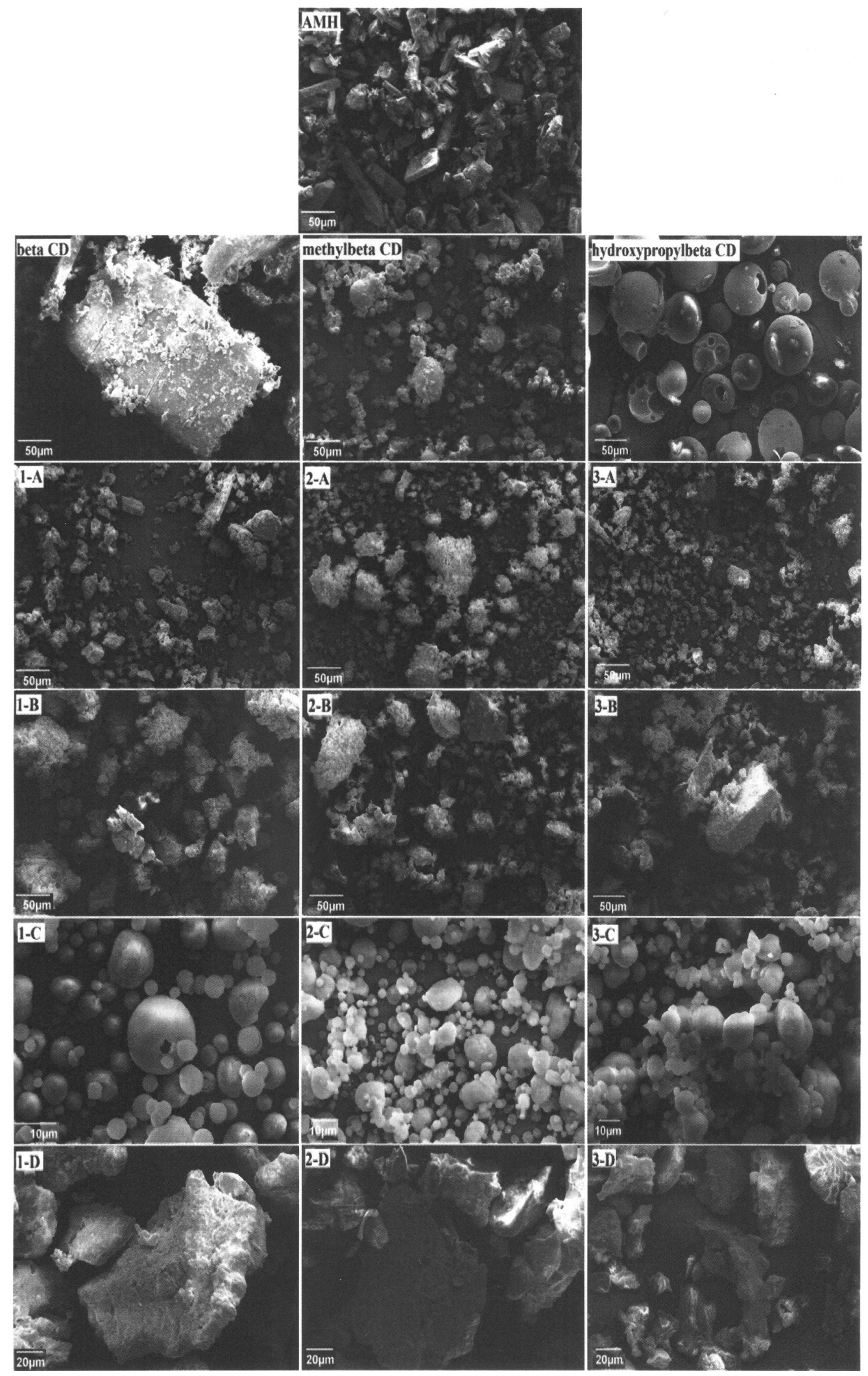

FIGURE 4 - Scanning Electronic Microscopy of AMH, beta-CD, methylbeta-CD, hydroxypropylbeta-CD, AMH/beta-CD/PM (1A), AMH/beta-CD/CE (1B), AMH/beta-CD/SD (1C), AMH/beta-CD/FD (1D), AMH/methylbeta-CD/PM (2A), AMH/methylbeta$\mathrm{CD} / \mathrm{CE}(2 \mathrm{~B}), \mathrm{AMH} /$ methylbeta-CD/SD (2C), AMH/methylbeta-CD/FD (2D), AMH/hydroxypropylbeta-CD/PM (3A), AMH/ hydroxypropylbeta-CD/CE (3B), AMH/hydroxypropylbeta-CD/SD (3C) and AMH/hydroxypropylbeta-CD/FD (3D). 

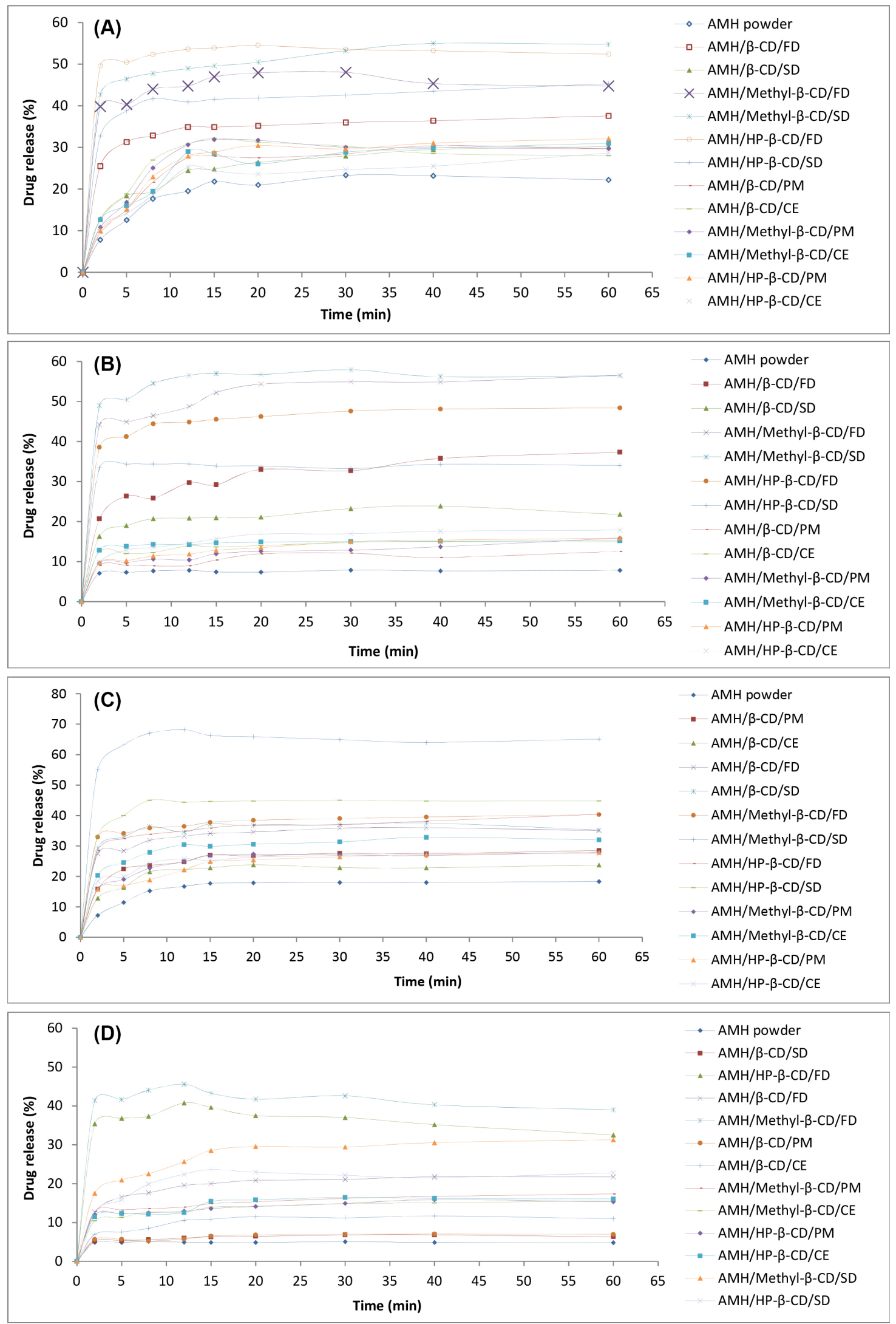

FIGURE 5 - Dissolution curves of AMH powder and different formulations using: (A) water, (B) acid buffer pH 1.2, (C) acetate buffer $\mathrm{pH} 4.5$ and (D) phosphate buffer $\mathrm{pH} 6.8$ as dissolution medium at $37^{\circ} \mathrm{C} \pm 0.5^{\circ} \mathrm{C}$. 
solubility, higher amorphization, wettability and capacity of complexation in solid state (Fernandes, Vieira, Veiga, 2002).

\section{CONCLUSIONS}

In the present work, the complex formed between AMH and CDs presented an enhanced solubility and dissolution rate for all complexes formed other than either physical mixture or pure drug. AMH solubility linearly increases with increasing concentrations of CDs of both temperatures indicating an $\mathrm{A}_{\mathrm{L}}$-type diagram over the entire concentration range evaluated. The $\Delta \mathrm{G}_{\mathrm{tr}}$ values were negative for all formulations indicating a spontaneous process which was thermodynamically favorable to drug solubility. The Kc result suggests good stability for both temperatures evaluated of the inclusion complex formed by AMH-Methyl- $\beta-C D$. The characterization of physicochemical results confirmed the formation of complexes with different cyclodextrins. The dissolution profiles of formulations demonstrated the great influence on drug solubility especially when prepared by the spraydrying method with methyl- $\beta-C D$ for all dissolution mediums evaluated. After studies using different CDs and complexation process, the results obtained demonstrated that the CDs are good excipients to increase molecule solubility.

\section{ACKNOWLEDGEMENTS}

The authors acknowledge the support of this work by Centro Universitário Franciscano, Santa Maria, Brazil and Prof. Marcos Segatto and Raphael Nicolay of the Federal University of Santa Catarina, Florianópolis, Brazil who performed microscopic and thermal analysis.

\section{REFERENCES}

ADELI, E. A comparative evaluation between utilizing SAS supercritical fluid technique and solvent evaporation method in preparation of Azithromycin solid dispersions for dissolution rate enhancement. J. Supercrit. Fluids, v.87, p.9-21, 2014

ALVES, L.D.S.; SOARES, M.F.R.; ALBUQUERQUE, C.T.; SILVA, E.R.; VIEIRA, A.C.C.; FONTES, D.A.; FIGUEIREDO, C.B.; SOBRINHO, J.L.; NETO, P.J. Solid dispersion of efavirens in PVP K-30 by conventional solvent and Kneading methods. Carbohydr. Polym., v.104, p.166174, 2014.
AMIDON, G.L.; LENNERNÃS, H.; SHAH, V.P.; CRISON, J.R. A theoretical basis for a biopharmaceutic drug classification: the correlation of in vitro drug product dissolution and in vivo bioavailability. Pharm. Res., v.12, n.3, p.413-420, 1995.

AVDEEF, A. Solubility of sparingly-soluble ionizable drugs. Adv. Drug. Deliv. Rev., v.59, n.7, p.568-590, 2007.

BABOOTA, S.; DHALIWAL, M.; KOHLI, K. Physicochemical characterization, in vitro dissolution behavior, and pharmacodynamic studies of rofecoxib-cyclodextrin inclusion compounds. Preparation and properties of rofecoxib hydroxypropyl $\beta$-cyclodextrin inclusion complex: a technical note. $A A P S$, v.6, n.1, p.83-90, 2005.

BANKAR, P.V.; MAHATMA, O.P. Improved dissolution rate of leflunomide using hydroxypropyl- $\boldsymbol{\beta}$-cyclodextrin inclusion complexation by Freeze-Drying Method. Int. J. Drug Deliv., v.4, n.4, p.498-506, 2012.

BENET, L.Z. There are no useful CYP3A probes that quantitatively predict the in vivo kinetics of other CYP3A substrates and no expectation that one will be found. Mol. Interv., v.5, n.2, p.79-83, 2005.

BOURY, F.; GAUTIER, J.; BOULIGAND, Y.; PROUST, J. Interfacial properties of amiodarone: the stabilizing effect of phosphate anions. Coll. Surf. B., v.20, n.3, p.219- 227, 2001.

BRITISH PHARMACOPOEIA. London: The Stationary Office, 2012. v.1, p.137-138.

CHAUDHARY, A.; NAGAICH, U.; GULATI, N.; SHARMA, V.K.; KHOSA, R.L. Enhancement of solubilization and bioavailability of poorly soluble drugs by physical and chemical modifications: a recent review. J. Adv. Pharm. Edu. Res., v.2, n.1, p.32-67, 2012.

DEL VALLE, E.M.M. Cyclodextrins and their uses: a review. Process Biochem., v.39, n.9, p.1033-1046, 2004.

EGHRARY, S.H.; ZARGHAMI, R.; MARTINEZ, F.; JOUYBAN, A. Solubility of 2-butyl-3-benzofuranyl 4-(2-(diethylamino)ethoxy-3,5-diiodophenyl ketone hydrochloride (Amiodarone $\mathrm{HCl}$ ) in ethanol + water and $\mathrm{N}$-methyl-2-pyrrolidone + water mixtures at various temperatures. J. Chem. Eng. Data, v.57, n.5, p.1544-1550, 2012. 
FERNANDES, C.M.; VIEIRA, M.T.; VEIGA, F.J.B. Physicochemical characterization and in vitro dissolution behavior of nicardipine-cyclodextrins inclusion compounds. Eur. J. Pharm. Sci., v.15, n.1, p.79-88, 2002.

FRIZON, F.; ELOY, J.O.; DONADUZZI, C.M.; MITSUI, M.L.; MARCHETTI, J.M. Dissolution rate enhancement of loratadine polyvinylpyrrolidone $\mathrm{K}-30$ solid dispersion by solvent methods. Powder Technol., v.235, p.532-539, 2013.

GURSOY, R.N.; BENITA, S. Self-emulsifying drug delivery systems (SEDDS) for improved oral delivery of lipophilic drugs. Biomed. Pharmacother, v.58, n.3, p.173-182, 2004.

HIGUCHI, T.; CONNORS, K.A. Phase solubility techniques. Adv. Anal. Chem. Instr., v.4, p.117-122, 1965.

JAGDALE, S.F.; JADHAV, V.N.; CHABUKSWAR, A.R.; KUCHEKAR, B.S. Solubility enhancement, physicochemical characterization and formulation of fastdissolving tablet of nifedipine-betacyclodextrin complexes. Braz. J. Pharm. Sci., v.48, n.1, p.131-145, 2012.

KU, M.S.; DUBLIN, W. A biopharmaceutical classificationbased right-first-time formulation approach to reduce human pharmacokinetic variability and project cycle time from first-in-human to clinical proof-of-concept. Pharm. Dev. Technol., v.17, n.3, p.285-302, 2012.

LAFUENTE-LAFUENTE, C.; ALVAREZ, J.C.; LEENHARDT, A.; MOULY, S.; EXTRAMIANA, F.; CAULIN, C.; FUNCK-BRENTANO, C.; BERGMANN, J. Amiodarone concentrations in plasma and fat tissue during chronic treatment and related toxicity. Brit. J. Clin. Pharmacol., v.67, n.5, p.511-519, 2009.

LAMPRECHT, A.; BOULIGAND, Y.; BENOIT, J. New lipid nanocapsules exhibit sustained release properties for amiodarone. J. Control Rel., v.84, n.1-2, p.59-68, 2002.

LEUNER, C.; DRESSMAN, J. Improving drug solubility for oral delivery using solid disperions. Eur. J. Pharm. Biopharm., v.50, n.1, p.47-60, 2000.

LI-HONG, W.; XIN, C.; HUI, X.; LI-LI, Z.; JING, H.; MEIJUAN, Z.; JIE, L.; YI, L.; JIN-WEN, L.; WEI, Z.; GANG, C. A novel strategy to design sustained-release poorly water-soluble drug mesoporous silica microparticles based on supercritical fluid technique. Int. J. Pharm., v.454, n.1, p.135-142, 2013.
LOFTSSON, T.; BREWSTER, M.E. Pharmaceutical applications of cyclodextrins. 1. drug solubilization and stabilization. J. Pharm. Sci., v.85, n.10, p.1017-1025, 1996.

LU, Y.; GUO, T.; QI, J.; ZHANG, J.; WU, W. Enhancement dissolution and stability of lansoprazole by cyclodextrin inclusion complexation: preparation, characterization and molecular modeling. AAPS, v.13, n.4, p.1222-1229, 2012.

MARKOVICH, R.J.; EVANS, C.A.; COSCOLLUELA, C.B.; ZIBAS, S.A.; ROSEN, J. Spectroscopic identification of an amorphous-to-crystalline drug transition in a solid dispersion SCH 48461 capsule formulation. J. Pharm. Biomed., v.16, n.4, p.661-673, 1997.

MAULVI, F.A.; DALWADI, S.J.; THAKKAR, V.T.; SONI, T.G.; GOHEL, M.C.; GANDHI, T.R. Improvement of dissolution rate of aceclofenac by solid dispersion technique. Powder Technol., v.207, n.1-3, p.47-54, 2011.

NAIDU, N.B.; CHOWDARY, K.P.; MURTHY, K.V.; SATYANARAYANA, V.; HAYMAN, A.R.; BECKET, G. Physicochemical characterization and dissolution properties of meloxican-cyclodextrin binary systems. J. Pharm. Biomed., v.35, n.1, p.75-86, 2004.

PADURARU, O.M.; BOSÎNCEANU, A.; TÂNTARU, G.; VASILE, C. Effect of hydroxypropryl- $\beta$-cyclodextrin on the solubility of an antiarrhythmic agent. Ind. Eng. Chem. Res., v.52, n.5, p.2174-2181, 2013.

PATEL, R.P.; PATEL, D.J.; BHIMANI, D.B.; PATEL, J.K. Physicochemical characterization and dissolution study of solid dispersions of furosemide with Polyethylene Glycol 6000 and Polyvinylpyrrolidone K30. Dissolut. Technol., v.15, n.3, p.17-25, 2008.

RAJEWSKI, R.A.; STELLA, V.J. Pharmaceutical applications of cyclodextrins. 2. In vivo drug delivery. J. Pharm. Sci., v.85, n.11, p.1142-1169, 1996.

RAVIN, L.J.; SHAMI, E.G.; RATTIE, E.S. Micelle formation and its relationship to solubility behavior of 2-butyl-3-benzofuranyl-4-(2-(diethylamino)ethoxy)3,5diiodophenylketone hydrochloride. J. Pharm. Sci., v.64, p.1830-1833, 1975. 
RIEKES, M.K.; TAGLIARI, M.P.; GRANADA, A.; KUMINEK, G.; SILVA, M.A.S.; STULZER, H. K. Enhanced solubility and dissolution rate of amiodarone by complexation with $\beta$-cyclodextrin through different methods. Mater. Sci. Eng. C.: Mater Biol. Appl., v.30, n.7, p.1008-1013, 2010.

RUBIM, A.M.; RUBENICK, J.B.; GREGOLIN, E.; LAPORTA, L.V.; LEITENBERG, R.; ROLIM, C.M.B. Amiodarone Hydrochloride: enhancement of solubility and dissolution rate by solid dispersion technique. Braz. J. Pharm. Sci., v.51, n.4, p.957-966, 2015.

SATHIGARI, S.; CHADHA, G.; LEE, P.; WRIGHT, N.; PARSONS, D.L.; RANGARI, V.K. Physicochemical characterization of efavirenz-cyclodextrin inclusion complexes. AAPS, v.10, n.1, p.81-87, 2009.

SVENSON, S. Dendrimers as versatile platform in drug delivery application. Eur. J. Pharm. Biopharm., v.71, n.3, p.445-462, 2009

UEKAMA, K. Design and evaluation of cyclodextrin-based drug formulation. Chem. Pharma. Bull., v.52, n.8, p.900915,2004
VASCONCELOS, T.; SARMENTO, B.; COSTA, P. Solid dispersions as strategy to improve oral bioavailability of poor water soluble drugs. Drug Discov. Today, v.12, n.2324, p.1068-1075, 2007.

VECCHIO, S.; RODANTE, F.; TOMASSETTI, M. Thermal stability of disodium and calcium phosphomycin and the effects of the excipents evaluated by thermal analysis. $J$. Pharm.. Biomed., v.24, n.5-6, p.1111-1123, 2001.

YOSHIDA, M.I.; GOMES, E.C.L.; SOARES, C.D.V.; OLIVEIRA, M.A. Thermal behavior study and decomposition kinetics of Amiodarone Hydrochloride under isothermal conditions. Drug. Dev. Ind. Pharm., v.37, n.6, p.638-647, 2011.

Received for publication on $11^{\text {st }}$ April 2016 Accepted for publication on $22^{\text {nd }}$ February 2017 